\title{
A Ground-Based Method of Assessing Urban Forest Structure and Ecosystem Services
}

\author{
David J. Nowak, Daniel E. Crane, Jack C. Stevens, Robert E. Hoehn, Jeffrey T. Walton, and \\ Jerry Bond
}

\begin{abstract}
To properly manage urban forests, it is essential to have data on this important resource. An efficient means to obtain this information is to randomly sample urban areas. To help assess the urban forest structure (e.g., number of trees, species composition, tree sizes, health) and several functions (e.g., air pollution removal, carbon storage and sequestration), the Urban Forest Effects (UFORE) model was developed. Data collection variables and model methods are detailed and urban forest structure results are compared among 14 United States cities with average tree density ranging between 22.5 trees/ha (9.1 trees/ac) in Casper, Wyoming, U.S. to 275.8 trees/ha (111.6 trees/ac) in Atlanta, Georgia, U.S. Advantages and disadvantages of this ground-based method of assessing urban forest structure, functions, and values are discussed.
\end{abstract}

Key Words. Air pollution removal; carbon sequestration; tree measurement; urban forest monitoring; urban forest sampling.

Urban vegetation, particularly trees, provides numerous benefits that can improve environmental quality and human health in and around urban areas. These benefits include improvements in air and water quality, building energy conservation, cooler air temperatures, reductions in ultraviolet radiation, and many other environmental and social benefits (e.g., Dwyer et al. 1992; Kuo and Sullivan 2001; Westphal 2003; Wolf 2003; Nowak and Dwyer 2007). Statistically sound data on the urban forest structure are required to properly assess the magnitude of these benefits. To optimize forest benefits, information on costs associated with vegetation management should also be assessed. Forest structural data (e.g., number of trees, species composition, tree size, health, tree location) provide the basis to estimate total leaf area, tree and leaf biomass, and quantify numerous forest functions (ecosystem services). Accurate measures of urban forest structure are critical for proper urban forest planning to help sustain or enhance environmental quality and human health and well-being in cities.

The most precise way to assess urban forest structure is to measure and record information on every tree. A complete census may work well for relatively small populations (e.g., street trees, small parks) but is cost-prohibitive for larger tree populations. Thus, random sampling can provide a cost-effective means to assess urban forest structure and functions for large-scale assessments. A limited number of assessments of entire urban forest ecosystems across a city based on ground sampling of individual trees has been conducted. Various studies in the past have attained information on urban forest structure and factors affecting structure, but these assessments focused on relatively small areas, subsets of the landscape, or tree cover attributes (e.g., Jones 1957; Derrenbacher 1969; Hyams 1970; Duncan 1973; Schmid 1975; Numata 1977; Sukopp et al. 1979; Kunick 1982; Boyd 1983; Iizumi 1983; Sanders 1983; Santamour 1983; Dorney et al. 1984; Moran 1984; Profous 1984; Richards et al. 1984; Rowntree 1984; Whitney 1985; Profous et al. 1988; Gilbert 1989; Jim 1989). More recently, increasing numbers of comprehensive assessments of urban forest structure have been conducted using sampling techniques (e.g., McBride and Jacobs
1976, 1986; Miller and Winer 1984; Nowak 1991, 1994b; McPherson 1998; Nowak and O'Connor 2001; Nowak et al. 2002b, 2006b, 2006c, 2006d, 2007b, 2007c, 2007d; Ham et al. 2003; Lozano 2004; Yang et al. 2005; Escobedo et al. 2006; McNeil and Vava 2006; Buckelew Cumming et al. 2007). The Urban Forest Effects (UFORE) model was developed to aid in assessing urban forest structure, functions, and values (Nowak and Crane 2000). This model contains protocols to measure and monitor urban forests as well as estimate ecosystem functions and values.

The UFORE model has been used in approximately 50 cities across the globe (approximately one-third outside of the United States) to assess urban tree populations using a standardized approach (e.g., Nowak and O'Connor 2001; Nowak et al. 2002b, 2006b, 2006c, 2006d, 2007b, 2007c, 2007d; Ham et al. 2003; Lozano 2004; Yang et al. 2005; Escobedo et al. 2006; McNeil and Vava 2006; Buckelew Cumming et al. 2007). Many of these cities were analyzed in cooperation with local institutions. Some cities have published reports, whereas others have used the model outputs without producing reports or have reports currently in production.

An understanding of the UFORE model operation and its advantages and disadvantages are critical to understanding the accuracy and purpose of the model as well as its strengths and limitations. Through this understanding, the model can be more fully used to improve urban forest assessments and enhance planning and management to sustain ecosystem services in urban and urbanizing areas. This article reviews the data collection required by the model and then details the methods of how structure and functions are estimated, including a discussion of the advantages and disadvantages of the approaches used. The article concludes with a discussion of how UFORE results can be integrated within long-term management plans.

\section{METHODS}

The basic premise behind the UFORE model is that urban forest structure affects forest functions and values. By having an accurate assessment of urban forest structure, better estimates of 
functions and values can be produced. The model uses a sampling procedure to estimate various measured structural attributes about the forest (e.g., species composition, number of trees, diameter distribution) within a known sampling error. The model uses the measured structural information to estimate other structural attributes (e.g., leaf area, tree and leaf biomass) and incorporates local environmental data to estimate several functional attributes (e.g., air pollution removal, carbon sequestration, building energy effects). Economic data from the literature are used to estimate the value of some of the functions. The model has the following five modules.

\section{Urban Forest Structure}

Urban forest structure is the spatial arrangement and characteristics of vegetation in relation to other objects (e.g., buildings) within urban areas (e.g., Nowak 1994a). This module quantifies urban forest structure (e.g., species composition, tree density, tree health, leaf area, leaf and tree biomass), value, diversity, and potential risk to pests.

\section{Sampling}

Urban Forest Effect model assessments have used two basic types of sampling to quantify urban forest structure: randomized grid and stratified random sampling. With the randomized grid sampling, the study area is divided into equal-area grid cells based on the desired number of plots and then one plot is randomly located within each grid cell. The study area can then be subdivided into smaller units of analysis (i.e., strata) after the plots are distributed (poststratification). Plot distribution among the strata will be proportional to the strata area. This random sampling approach allows for relatively easy assessment of changes through future measurements (urban forest monitoring), but likely at the cost of increased variance (uncertainty) of the population estimates.

With stratified random sampling, the study area is stratified before distributing the plots and plots are randomly distributed within each stratum (e.g., land use). This process allows the user to distribute the plots among the strata to potentially decrease the overall variance of the population estimate. For example, because tree effects are often the primary focus of sampling, the user can distribute more plots into strata that have more trees. The disadvantage of this approach is that it makes long-term change assessments more difficult as a result of the potential for strata to change through time.

There is no significant difference in cost or time to establish plots regardless of sampling methods for a fixed number of plots. However, there are likely differences in estimate precision. Prestratification, if done properly, can reduce overall variance because it can focus more plots in areas of higher variability. Any plot size can be used in UFORE, but the typical plot size used is $0.04 \mathrm{ha}(0.1 \mathrm{ac})$. The number and size of plots will affect total cost of the data collection as well as the variance of the estimates (Nowak et al. 2008).

\section{Data Collection Variables}

There are four general types of data collected on a UFORE plot: 1) general plot information (Table 1) used to identify the plot and its general characteristics; 2) shrub information (Table 2) used to estimate shrub leaf area/biomass, pollution removal, and volatile organic compound (VOC) emissions by shrubs; 3 ) tree information (Table 3) used to estimate forest structural attributes, pollution removal, VOC emissions, carbon storage and sequestration, energy conservation effects, and potential pest impacts of trees; and 4) ground cover data used to estimate the amount and distribution of various ground cover types in the study area.

Typically, shrubs are defined as woody material with a diameter at breast height (dbh; height at $1.37 \mathrm{~m}$ [4.5 ft]) less than 2.54 $\mathrm{cm}$ ( 1 in), whereas trees have a dbh greater than or equal to 2.54 $\mathrm{cm}$ ( 1 in). Trees and shrubs can also be differentiated by species (i.e., certain species are always a tree or always a shrub) or with a different dbh minimum threshold. For example, in densely forested areas, increasing the minimum dbh to $12.7 \mathrm{~cm}$ (5 in) can

Table 1. General plot information collected for the UFORE Model.

\begin{tabular}{|c|c|}
\hline Variable & Description \\
\hline Plot ID ID $^{2}$ & Unique identifier \\
\hline \multicolumn{2}{|l|}{ Plot address $^{\mathrm{y}}$} \\
\hline \multicolumn{2}{|l|}{ Date and crew } \\
\hline Photo number & Used to help identify plot \\
\hline Measurement units ${ }^{z}$ & Units for all measurement in the plot; metric $(\mathrm{m} / \mathrm{cm})$ or English $(\mathrm{ft} / \mathrm{in})$ \\
\hline Reference objects ${ }^{\mathrm{y}}$ & At least two objects that will assist in locating plot center for future plot remeasurements \\
\hline Distance to reference object ${ }^{\mathrm{y}}$ & Distance from plot center to each reference object ( $\mathrm{ft}$ or $\mathrm{m}$ ) \\
\hline Direction to object ${ }^{\mathrm{y}}$ & Direction from plot center to each reference object (degrees) \\
\hline Tree measurement point $(\mathrm{TMP})^{\mathrm{y}}$ & $\begin{array}{l}\text { If plot center falls on a building or other surface (such as a highway) where plot center cannot be accessed, } \\
\text { the plot is not moved; all distances and directions to trees are measured and recorded from a recorded } \\
\text { fixed point (e.g., building corner) referred to as the TMP }\end{array}$ \\
\hline Percent measured ${ }^{\mathrm{z}}$ & Proportion of the plot that is actually measured as portions of plot may be denied access \\
\hline Land use $\mathrm{z}^{\mathrm{z}}$ & As determined by crew in the field from a standard list of land uses \\
\hline Percent in ${ }^{\mathrm{z}}$ & Proportion of the plot in each land use to nearest $1 \%$ \\
\hline Tree cover ${ }^{\mathrm{z}}$ & Percent of plot area covered by tree canopies estimated to nearest $5 \%$ \\
\hline Shrub cover ${ }^{2}$ & Percent of plot area covered by shrub canopies estimated to nearest $5 \%$ \\
\hline Plantable space & $\begin{array}{l}\text { Percent of plot area that is plantable for trees (i.e., plantable soils space not filled with tree canopies) and } \\
\text { tree planting would not be restricted as a result of land use (footpath, baseball field, and so on); to } \\
\text { nearest } 5 \%\end{array}$ \\
\hline
\end{tabular}

${ }^{\mathrm{z}}$ Required for UFORE analysis.

${ }^{\mathrm{y}}$ Required for permanent reference of plot.

UFORE $=$ Urban Forest Effects. 
Table 2. Shrub information collected for the UFORE Model.

\begin{tabular}{ll}
\hline Variable & Description \\
\hline Species code & Species code from standard list currently containing over 10,000 tree and shrub species \\
Average height of mass & Where mass is a group of shrubs species or genera of similar height (ft or m) \\
Percent area & Percent of total shrub cover on plot occupied by shrub mass \\
Percent shrub mass missing & Percent of shrub mass volume (height $\times$ ground area) that is not occupied by leaves; estimated to nearest $5 \%$
\end{tabular}

UFORE $=$ Urban Forest Effects.

substantially reduce the field work by decreasing the number of trees measured, but less information on trees will be attained.

Woody plants that are not $30.5 \mathrm{~cm}$ (12 in) in height are considered herbaceous cover (e.g., seedlings). Shrub masses within each plot are divided into groups of same species and size, and for each group, appropriate data are collected (Table 2). Tree variables (Table 3 ) are collected on every measured tree.

Field data are collected during the in-leaf season to help assess crown parameters and health. More detailed information on plot data collection methods and equipment can be found in the i-Tree User's Manual (i-Tree 2008).

\section{Leaf Area and Leaf Biomass}

Leaf area and leaf biomass of individual open-grown trees (crown light exposure [CLE] of 4 to 5) are calculated using regression equations for deciduous urban species (Nowak 1996). If shading coefficients (percent light intensity intercepted by foliated tree crowns) used in the regression did not exist for an individual species, genus or hardwood averages are used. For deciduous trees that are too large to be used directly in the regression equation, average leaf area index (LAI: $\mathrm{m}^{2}$ leaf area per $\mathrm{m}^{2}$ projected ground area of canopy) is calculated by the regression equation for the maximum tree size based on the appropriate height-width ratio and shading coefficient class of the tree. This LAI is applied to the ground area $\left(\mathrm{m}^{2}\right)$ projected by the tree's crown to calculate leaf area $\left(\mathrm{m}^{2}\right)$. For deciduous trees with height-to-width ratios that are too large or too small to be used directly in the regression equations, tree height or width is scaled downward to allow the crown to the reach maximum (2) or minimum (0.5) height-to-width ratio. Leaf area is calculated using the regression equation with the maximum or minimum ratio; leaf area is then scaled back proportionally to reach the original crown volume.

For conifer trees (excluding pines), average LAI per heightto-width ratio class for deciduous trees with a shading coefficient of 0.91 is applied to the tree's ground area to calculate leaf area. The 0.91 shading coefficient class is believed to be the best class to represent conifers because conifer forests typically have approximately 1.5 times more LAI than deciduous forests (Barbour et al. 1980) and 1.5 times the average shading coefficient for deciduous trees (0.83; see Nowak 1996) is equivalent to LAI of the 0.91 shading coefficient. Because pines have lower LAI than other conifers and LAI that are comparable to hardwoods (e.g., Jarvis and Leverenz 1983; Leverenz and Hinckley 1990), the average shading coefficient $(0.83)$ is used to estimate pine leaf area.

Leaf biomass is calculated by converting leaf area estimates using species-specific measurements of grams of leaf dry

Table 3. Tree variables collected for UFORE analysis with associated reason for data collection.

\begin{tabular}{|c|c|}
\hline Variable & Description \\
\hline Tree ID & Unique tree number \\
\hline $\begin{array}{l}\text { Distance }(\mathrm{ft} / \mathrm{m}) \text { and direction (degrees) from plot } \\
\text { center or } \mathrm{TMP}^{\mathrm{z}}\end{array}$ & Used to identify and locate trees for future measurements; TMP is tree measurement point (Table 1) \\
\hline Species $\operatorname{code}^{\mathrm{y}}(\mathrm{A}, \mathrm{C}, \mathrm{E}, \mathrm{S}, \mathrm{V})$ & Species code from standard list currently containing over 10,000 tree and shrub species \\
\hline Number of dbhs recorded ${ }^{\mathrm{y}}$ & For multistemmed trees \\
\hline $\operatorname{Dbh}^{\mathrm{y}}(\mathrm{C}, \mathrm{S})$ & Diameter at breast height $(\mathrm{in} / \mathrm{cm})$ for all recorded stems \\
\hline Dbh measurement height & Recorded if dbh is not measured at $1.37 \mathrm{~m}(4.5 \mathrm{ft})$ \\
\hline Total height $^{\mathrm{y}}(\mathrm{A}, \mathrm{C}, \mathrm{E}, \mathrm{S}, \mathrm{V})$ & Height to top of tree $(\mathrm{ft} / \mathrm{m})$ \\
\hline Height to crown base ${ }^{\mathrm{y}}(\mathrm{A}, \mathrm{S}, \mathrm{V})$ & Height to base of live crown $(\mathrm{ft} / \mathrm{m})$ \\
\hline Crown width ${ }^{\mathrm{y}}(\mathrm{A}, \mathrm{S}, \mathrm{V})$ & Recorded by two measurements: N-S (north-south) and E-W (east-west) widths (ft/m) \\
\hline Percent canopy missing ${ }^{\mathrm{y}}(\mathrm{A}, \mathrm{S}, \mathrm{V})$ & $\begin{array}{l}\text { The percent of the crown volume that is not occupied by leaves; two perpendicular measures of } \\
\text { missing leaf mass are made and the average result is recorded; recorded to nearest } 5 \%\end{array}$ \\
\hline $\operatorname{Dieback}^{\mathrm{y}}(\mathrm{C}, \mathrm{E}, \mathrm{S})$ & Percent crown dieback to nearest $5 \%$ \\
\hline Percent impervious beneath canopy $(\mathrm{H})$ & Percent of land area beneath entire tree canopy's drip line that is impervious \\
\hline Percent shrub cover beneath canopy $(\mathrm{H})$ & Percent of land area beneath canopy drip line that is occupied by shrubs \\
\hline Crown light exposure ${ }^{\mathrm{y}}(\mathrm{C}, \mathrm{S})$ & $\begin{array}{l}\text { Number of sides of the tree receiving sunlight from above; used to estimate competition and growth } \\
\text { rates }\end{array}$ \\
\hline $\begin{array}{l}\text { Distance }(\mathrm{ft} / \mathrm{m}) \text { and direction (degrees) to } \\
\text { space-conditioned residential buildings }{ }^{\mathrm{y}}(\mathrm{E})\end{array}$ & $\begin{array}{l}\text { Measured for trees at least } 6.1 \mathrm{~m}(20 \mathrm{ft}) \text { tall and within } 18.3 \mathrm{~m}(60 \mathrm{ft}) \text { of structures three stories or } \\
\text { less in height }\end{array}$ \\
\hline Street tree & $\mathrm{Y} / \mathrm{N}$; used to estimate proportion of population that is street trees \\
\hline Tree status & Indicates if tree is new or removed from last measurement period \\
\hline
\end{tabular}

${ }^{\mathrm{z}}$ Required for permanent reference of plot.

${ }^{y}$ Required for UFORE analysis.

Variable used to assess: $\mathrm{A}=$ air pollution removal; $\mathrm{C}=$ carbon storage/sequestration; $\mathrm{E}=$ energy conservation; $\mathrm{H}=\mathrm{hydrologic}$ effects; $\mathrm{S}=$ structural information; $\mathrm{V}=$ VOC emissions.

UFORE = Urban Forest Effects. 
weight $/ \mathrm{m}^{2}$ of leaf area. Shrub leaf biomass is calculated as the product of the crown volume occupied by leaves $\left(\mathrm{m}^{3}\right)$ and measured leaf biomass factors $\left(\mathrm{g} / \mathrm{m}^{3}\right)$ for individual species (e.g., Winer et al. 1983; Nowak 1991). Shrub leaf area is calculated by converting leaf biomass to leaf area based on measured species conversion ratios $\left(\mathrm{m}^{2} / \mathrm{g}\right)$. As a result of limitations in estimating shrub leaf area by the crown-volume approach, shrub leaf area is not allowed to exceed a LAI of 18. If there are no leaf-biomassto-area or leaf-biomass-to-crown-volume conversion factors for an individual species, genus or hardwood/conifer averages are used.

For trees in more forest stand conditions (higher plant competition), LAI for more closed canopy positions (CLE $=0-1)$ is calculated using a forest leaf area formula based on the BeerLambert Law:

$$
\mathrm{LAI}=\ln \left(\mathrm{I} / \mathrm{I}_{\mathrm{o}}\right) /-\mathrm{k}
$$

where $\mathrm{I}=$ light intensity beneath canopy; $\mathrm{I}_{\mathrm{o}}=$ light intensity above canopy; and $\mathrm{k}=$ light extinction coefficient (Smith et al. 1991). The light extinction coefficients are 0.52 for conifers and 0.65 for hardwoods (Jarvis and Leverenz 1983). To estimate the tree leaf area (LA):

$$
\mathrm{LA}=\left[\ln \left(1-\mathrm{x}_{\mathrm{s}}\right) /-\mathrm{k}\right] \times \pi \mathrm{r}^{2}
$$

where $\mathrm{x}_{\mathrm{s}}$ is average shading coefficient of the species and $\mathrm{r}$ is the crown radius. For CLE $=2-3$ : LA is calculated as the average of leaf area from the open-grown (CLE $=4-5)$ and closed canopy equations (CLE $=0-1$ ).

Estimates of LA and leaf biomass are adjusted downward based on crown leaf dieback (tree condition). Trees are assigned to one of seven condition classes: excellent (less than $1 \%$ dieback); good ( $1 \%$ to $10 \%$ dieback); fair (11\% to $25 \%$ dieback); poor ( $26 \%$ to $50 \%$ dieback); critical ( $51 \%$ to $75 \%$ dieback); dying ( $76 \%$ to $99 \%$ dieback); and dead (100\% dieback). Condition ratings range between 1 indicating no dieback and 0 indicating $100 \%$ dieback (dead tree). Each class between excellent and dead is given a rating between 1 and 0 based on the midvalue of the class (e.g., fair $=11 \%$ to $25 \%$ dieback is given a rating of 0.82 or $82 \%$ healthy crown). Tree leaf area is multiplied by the tree condition factor to produce the final LA estimate.

\section{Species Diversity}

A species diversity index (Shannon-Wiener) and species richness (i.e., number of species) (e.g., Barbour et al. 1980) are calculated for living trees for the entire city. The proportion of the tree population that originated from different parts of the country and the world is calculated based on the native range of each species (e.g., Hough 1907; Grimm 1962; Platt 1968; Little 1971, 1976, 1977, 1978; Viereck and Little 1975; Preston 1976; Clark 1979; Burns and Honkala 1990a, 1990b; Gleason and Cronquist 1991).

\section{Structural Value}

The structural value of the trees (Nowak et al. 2002a) is based on methods from the Council of Tree and Landscape Appraisers (CTLA 1992). Compensatory value is based on four tree/site characteristics: trunk area (cross-sectional area at dbh), species, condition, and location. Trunk area and species are used to determine the basic value, which is then multiplied by condition and location ratings ( 0 to 1$)$ to determine the final tree compen- satory value. Local species factors, average replacement cost, and transplantable size and replacement prices are obtained from ISA publications. If no species data are available for the state, data from the nearest state are used. Condition factors are based on percent crown dieback. Available data required using location factors based on land use type (International Society of Arboriculture 1988): golf course $=0.8$; commercial/industrial, cemetery, and institutional $=0.75$; parks and residential $=0.6$; transportation and forest $=0.5$; agriculture $=0.4$; vacant $=$ 0.2 ; wetland $=0.1$

\section{Insect Effects}

The proportion of leaf area and live tree population and estimated compensatory value in various susceptibility classes to gypsy moth (Liebhold et al. 1995; Onstad et al. 1997), Asian longhorned beetle (e.g., Nowak et al. 2001), and emerald ash borer (ash species) are calculated to reveal potential urban forest damage associated with these pests.

\section{Biogenic Emissions}

Volatile organic compounds can contribute to the formation of $\mathrm{O}_{3}$ and CO (e.g., Brasseur and Chatfield 1991). The amount of VOC emissions depends on tree species, leaf biomass, air temperature, and other environmental factors. This module estimates the hourly emission of isoprene $\left(\mathrm{C}_{5} \mathrm{H}_{8}\right)$, monoterpenes $\left(\mathrm{C}_{10}\right.$ terpenoids), and other volatile organic compounds by species for each land use and for the entire city. Species leaf biomass (from the structure module) is multiplied by genus-specific emission factors (Nowak et al. 2002b) to produce emission levels standardized to $30^{\circ} \mathrm{C}\left(86^{\circ} \mathrm{F}\right)$ and photosynthetically active radiation (PAR) flux of $1000 \mu \mathrm{mol} / \mathrm{m}^{2} / \mathrm{s}$. If genus-specific information is not available, then median emission values for the family, order, or superorder are used. Standardized emissions are converted to actual emissions based on light and temperature correction factors (Geron et al. 1994) and local meteorological data. Because PAR strongly controls the isoprene emission rate, PAR is estimated at 30 canopy levels as a function of above-canopy PAR using the sunfleck canopy environment model (A. Guenther, Nat. Cent. for Atmos. Res., pers. comm., 1998) with the LAI from the structure calculations.

Hourly inputs of air temperature are from measured National Climatic Data Center (NCDC) meteorological data. Total solar radiation is calculated based on the National Renewable Energy Laboratory Meteorological/Statistical Solar Radiation Model with inputs from the NCDC data set (Maxwell 1994). PAR is calculated as $46 \%$ of total solar radiation input (Monteith and Unsworth 1990).

Because tree transpiration cools air and leaf temperatures and thus reduces biogenic VOC emissions, tree and shrub VOC emissions are reduced in the model based on air quality modeling results (Nowak et al. 2000). For the modeling scenario analyzed (July 13-15, 1995), increased tree cover reduced air temperatures by $0.3^{\circ} \mathrm{C}$ to $1.0^{\circ} \mathrm{C}$ resulting in hourly reductions in biogenic VOC emissions of $3.3 \%$ to $11.4 \%$. These hourly reductions in VOC emissions are applied to the tree and shrub emissions during the in-leaf season to account for tree effects on air temperature and its consequent impact on VOC emissions.

\section{Carbon Storage and Annual Sequestration}

This module calculates total stored carbon and gross and net carbon sequestered annually by the urban forest. Biomass for 
each measured tree is calculated using allometric equations from the literature (see Nowak 1994c; Nowak et al. 2002b). Equations that predict aboveground biomass are converted to whole tree biomass based on a root-to-shoot ratio of 0.26 (Cairns et al. 1997). Equations that compute fresh weight biomass are multiplied by species- or genus-specific conversion factors to yield dry weight biomass. These conversion factors, derived from average moisture contents of species given in the literature, averaged 0.48 for conifers and 0.56 for hardwoods (see Nowak et al. 2002b).

Open-grown, maintained trees tend to have less aboveground biomass than predicted by forest-derived biomass equations for trees of the same dbh (Nowak 1994c). To adjust for this difference, biomass results for urban trees are multiplied by a factor of 0.8 (Nowak 1994c). No adjustment is made for trees found in more natural stand conditions (e.g., on vacant lands or in forest preserves). Because deciduous trees drop their leaves annually, only carbon stored in wood biomass is calculated for these trees. Total tree dry weight biomass is converted to total stored carbon by multiplying by 0.5 (Forest Products Laboratory 1952; Chow and Rolfe 1989).

The multiple equations used for individual species were combined to produce one predictive equation for a wide range of diameters for individual species. The process of combining the individual formulas (with limited diameter ranges) into one more general species formula produced results that were typically within $2 \%$ of the original estimates for total carbon storage of the urban forest (i.e., the estimates using the multiple equations). Formulas were combined to prevent disjointed sequestration estimates that can occur when calculations switch between individual biomass equations.

If no allometric equation could be found for an individual species, the average of results from equations of the same genus is used. If no genus equations are found, the average of results from all broadleaf or conifer equations is used.

To estimate monetary value associated with urban tree carbon storage and sequestration, carbon values are multiplied by $\$ 22.8 /$ tonne of carbon ( $\$ 20.7 /$ ton of carbon) based on the estimated marginal social costs of carbon dioxide emissions for 2001 to 2010 (Fankhauser 1994).

\section{Urban Tree Growth and Carbon Sequestration}

To determine a base growth rate based on length of growing season, urban street tree (Fleming 1988; Frelich 1992; Nowak 1994c), park tree (deVries 1987), and forest growth estimates (Smith and Shifley 1984) were standardized to growth rates for 153 frost-free days based on: standardized growth $=$ measured growth $\times(153 /$ number of frost-free days of measurement $)$.

Average standardized growth rates for street (open-grown) trees were $0.83 \mathrm{~cm} /$ year $(0.33 \mathrm{in} /$ year $)$. Growth rates of trees of the same species or genera were then compared to determine the average difference between standardized street tree growth and standardized park and forest growth rates. Park growth averaged 1.78 times less than street trees, and forest growth averaged 2.29 times less than street tree growth. Crown light exposure measurements of 0 to 1 were used to represent forest growth conditions; 2 to 3 for park conditions; and 4 to 5 for open-grown conditions. Thus, the standardized growth equations are:

Standardized growth $(\mathrm{SG})=0.83 \mathrm{~cm} /$ year $(0.33 \mathrm{in} /$ year $) \times$ number of frost free days/153 and for: CLE 0-1: Base growth $=$
SG/2.26; CLE 2-3: base growth = SG /1.78; and CLE 4-5: base growth $=\mathrm{SG}$.

Base growth rates are adjusted based on tree condition. For trees in fair to excellent condition, base growth rates are multiplied by 1 (no adjustment), poor trees' growth rates are multiplied by 0.76 , critical trees by 0.42 , dying trees by 0.15 , and dead trees by 0 . Adjustment factors are based on percent crown dieback and the assumption that less than $25 \%$ crown dieback had a limited effect on dbh growth rates. The difference in estimates of carbon storage between year $x$ and year $x+1$ is the gross amount of carbon sequestered annually.

\section{Air Pollution Removal}

This module quantifies the hourly amount of pollution removed by the urban forest, its value, and associated percent improvement in air quality throughout a year. Pollution removal and percent air quality improvement are calculated based on field, pollution concentration, and meteorologic data.

This module is used to estimate dry deposition of air pollution (i.e., pollution removal during nonprecipitation periods) to trees and shrubs (Nowak et al. 1998, 2000). This module calculates the hourly dry deposition of ozone $\left(\mathrm{O}_{3}\right)$, sulfur dioxide $\left(\mathrm{SO}_{2}\right)$, nitrogen dioxide $\left(\mathrm{NO}_{2}\right)$, carbon monoxide $(\mathrm{CO})$, and particulate matter less than $10 \mu \mathrm{m}$ (PM10) to tree and shrub canopies throughout the year based on tree-cover data, hourly NCDC weather data, and U.S. Environmental Protection Agency pollution concentration monitoring data.

The pollutant flux $\left(\mathrm{F}\right.$; in $\left.\mathrm{g} / \mathrm{m}^{2} / \mathrm{s}\right)$ is calculated as the product of the deposition velocity $\left(\mathrm{V}_{\mathrm{d}}\right.$; in $\left.\mathrm{m} / \mathrm{s}\right)$ and the pollutant concentration $\left(\mathrm{C}\right.$; in $\left.\mathrm{g} / \mathrm{m}^{3}\right)$ :

$$
\mathrm{F}=\mathrm{V}_{\mathrm{d}} \times \mathrm{C}
$$

Deposition velocity is calculated as the inverse of the sum of the aerodynamic $\left(\mathrm{R}_{\mathrm{a}}\right)$, quasilaminar boundary layer $\left(\mathrm{R}_{\mathrm{b}}\right)$, and canopy $\left(R_{c}\right)$ resistances (Baldocchi et al. 1987):

$$
\mathrm{V}_{\mathrm{d}}=\left(\mathrm{R}_{\mathrm{a}}+\mathrm{R}_{\mathrm{b}}+\mathrm{R}_{\mathrm{c}}\right)^{-1}
$$

Hourly meteorologic data from the closest weather station (usually airport weather stations) are used in estimating $\mathrm{R}_{\mathrm{a}}$ and $\mathrm{R}_{\mathrm{b}}$. In-leaf, hourly tree canopy resistances for $\mathrm{O}_{3}, \mathrm{SO}_{2}$, and $\mathrm{NO}_{2}$ are calculated based on a modified hybrid of big leaf and multilayer canopy deposition models (Baldocchi et al. 1987; Baldocchi 1988).

Because $\mathrm{CO}$ and removal of particulate matter by vegetation are not directly related to transpiration, $\mathrm{R}_{\mathrm{c}}$ for $\mathrm{CO}$ is set to a constant for in-leaf season $(50,000 \mathrm{sec} / \mathrm{m}[15,240 \mathrm{sec} / \mathrm{ft}])$ and leaf-off season $(1,000,000 \mathrm{sec} / \mathrm{m}[304,800 \mathrm{sec} / \mathrm{ft}])$ based on data from Bidwell and Fraser (1972). For particles, the median deposition velocity from the literature (Lovett 1994) is $0.0128 \mathrm{~m} / \mathrm{s}$ $(0.042 \mathrm{ft} / \mathrm{s})$ for the in-leaf season. Base particle $\mathrm{V}_{\mathrm{d}}$ is set to 0.064 $\mathrm{m} / \mathrm{s}(0.021 \mathrm{ft} / \mathrm{s})$ based on a LAI of 6 and a $50 \%$ resuspension rate of particles back to the atmosphere (Zinke 1967). The base $V_{d}$ is adjusted according to actual LAI and in-leaf versus leaf-off season parameters. Bounds of total tree removal of $\mathrm{O}_{3}, \mathrm{NO}_{2}, \mathrm{SO}_{2}$, and PM10 are estimated using the typical range of published in-leaf dry deposition velocities (Lovett 1994). Percent air quality improvement is estimated by incorporating local or regional boundary layer height data (height of the pollutant mixing layer). More detailed methods on this module can be found in Nowak et al. (2006a). 
The monetary value of pollution removal by trees is estimated using the median externality values for the United States for each pollutant. These values, in dollars per tonne (metric ton [mt]) are: $\mathrm{NO}_{2}=\$ 6,752 \mathrm{mt}^{-1}\left(\$ 6,127 \mathrm{t}^{-1}\right), \mathrm{PM} 10=\$ 4,508 \mathrm{mt}^{-1}$ $\left(\$ 4,091 \mathrm{t}^{-1}\right), \mathrm{SO}_{2}=\$ 1,653 \mathrm{mt}^{-1}\left(\$ 1,500 \mathrm{t}^{-1}\right)$, and $\mathrm{CO}=\$ 959$ $\mathrm{mt}^{-1}\left(\$ 870 \mathrm{t}^{-1}\right)$ (Murray et al. 1994). Recently, these values were adjusted to 2007 values based on the producer's price index (Capital District Planning Commission 2008) and are now (in dollars per metric ton $[\mathrm{mt}]): \mathrm{NO}_{2}=\$ 9,906 \mathrm{mt}^{-1}\left(\$ 8,989 \mathrm{t}^{-1}\right)$, PM10 $=\$ 6,614 \mathrm{mt}^{-1}\left(\$ 6,002 \mathrm{t}^{-1}\right), \mathrm{SO}_{2}=\$ 2,425 \mathrm{mt}^{-1}(\$ 2,201$ $\left.\mathrm{t}^{-1}\right)$, and $\mathrm{CO}=\$ 1,407 \mathrm{mt}^{-1}\left(\$ 1,277 \mathrm{t}^{-1}\right)$. Externality values for $\mathrm{O}_{3}$ are set to equal the value for $\mathrm{NO}_{2}$.

\section{Building Energy Effects}

This module estimates the effects of trees on building energy use and consequent emissions of carbon from power plants. Methods for these estimates are based on a report by McPherson and Simpson (1999). Distance and direction to the building is recorded for each tree within $18.3 \mathrm{~m}$ (60 ft) of two- or one-story residential buildings. Any tree that is smaller than $6.1 \mathrm{~m}(20 \mathrm{ft})$

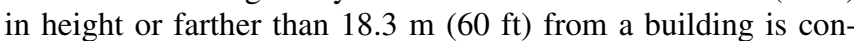
sidered to have no effect on building energy use.

Using the tree size, distance, direction to building, climate region, leaf type (deciduous or evergreen), and percent cover of buildings and trees on the plot, the amount of carbon avoided from power plants as a result of the presence of trees is calculated. The amount of carbon avoided is categorized into the amount of MWh (cooling) and MBtus and MWh (heating) avoided as a result of tree energy effects. Default energy effects per tree are set for each climate region, vintage building types (period of construction), tree size class, distance from building, energy use (heating or cooling), and/or leaf type (deciduous or evergreen) depending on the energy effect of the tree (tree shade, windbreak effects, and local climate effect) (McPherson and Simpson 1999). Default shading and climate effect values are applied to all trees; heating windbreak energy effects are assigned to each evergreen tree. Because shading effect default values are given for only one vintage building type (post-1980), vintage adjustment factors (McPherson and Simpson 1999) are applied to obtain shading effect values for all other vintage types.

\section{Tree Condition Adjustment}

The default energy effect values (McPherson and Simpson 1999) are adjusted for the tree condition as follows:

$$
\text { Energy adjustment }=0.5+(0.5 \times \text { tree condition })
$$

where tree condition $=1-\%$ dieback. This adjustment factor is applied to all tree energy effects for cooling, but only evergreen trees for the heating energy use effects because deciduous trees are typically out of leaf during the heating season.

\section{Local Climate Effects}

The individual tree effect on climate diminishes as tree cover increases in an area, although the total effect of all trees can increase. Base climate effect values for a tree are given for plots of $10 \%, 30 \%$, and $60 \%$ cover (McPherson and Simpson 1999). Interpolation formulas (McPherson and Simpson 1999) are used to determine the actual tree value based on the specific plot percent tree and building cover. For plots with less than $10 \%$ cover, the slope between the $10 \%$ and $30 \%$ cover values are used for the interpolation. Plots with percent cover greater than $60 \%$ used the slope between $30 \%$ and $60 \%$ cover with a minimum individual tree climate effect of one-third the effect at $60 \%$ cover. This minimum is set to prevent a tree from obtaining a negative effect at high cover.

The total shading, windbreak, and climate energy effects resulting from trees on a plot are calculated by summing the individual tree's energy effects for the particular energy use and housing vintage. These values are adjusted for the distribution of the different vintage types within the climate region (McPherson and Simpson 1999).

Because the default cooling energy effects are determined based on the climate regions' electricity emissions factors, it is necessary to convert the cooling energy effects to the statespecific equivalent. This conversion is accomplished by multiplying the plot cooling energy effects by the ratio of the statespecific electricity emissions factor to the climate region's electricity emissions factor (McPherson and Simpson 1999).

Home heating source distribution (e.g., fuel oil, heat pump, electricity, and natural gas) for the region is used to partition the carbon emissions from heating to the appropriate energy source. Standard conversion factors ( $\left.\mathrm{t} \mathrm{CO}_{2} / \mathrm{MWh}, \mathrm{t} \mathrm{CO}_{2} / \mathrm{MBtu}\right)$ are used to convert the energy effect from $\mathrm{CO}_{2}$ to units of energy saved (MBtus, MWh). Cooling and heating electricity use (MWh) had state-specific conversion factors; nonelectrical heating fuels (MBtus) used a standard conversion factor because this factor does not vary by region (McPherson and Simpson 1999). Total plot effects are combined to yield the total energy and associated carbon effect resulting from the urban forest.

To determine the estimated economic impact of the change in building energy use, state average price per kWh between 1970 and 2002 (Energy Information Administration 2003a) and per MBtu for natural gas, residential fuel, and wood between 1990 and 2002 (Energy Information Administration 2003b, 2003c, 2003d, 2003e, 2003f) are used. All prices are adjusted to 2002 dollars using the consumer price index (U.S. Department of Labor and Statistics 2003). State prices are used to determine the value of energy effects. Average price for heating change resulting from trees is based on the average distribution of buildings in the region that heat by natural gas, fuel oil, and other (including wood) (McPherson and Simpson 1999).

\section{RESULTS}

Urban forest structure can vary among cities based on the local environment (e.g., forest versus desert), land use distribution, and population density (Nowak et al. 1996). Based on the analyses of 14 cities, the total number of trees in a city varied from 48,000 in Freehold, New Jersey, U.S. to 9.4 million in Atlanta, Georgia, U.S. (Table 4). Because size of city can significantly influence the total number of trees, tree density (trees per hectare) yields a more standardized index of urban forest structure by which to compare cities. Tree density among the cities varied from 22.5 trees/ha (9.1 trees/ac) in Casper, Wyoming, to 275.8 trees/ha (111.6 trees/ac) in Atlanta (Table 4). Tree cover varied among cities from $8.9 \%$ in Casper to $36.7 \%$ in Atlanta. The most common species found in the 14 sampled cities include a mix of native and exotic species (Table 4). The estimated city leaf area index (total leaf area [one-sided]/city area) for trees across a city ranged from 0.3 in Casper to 2.2 in Atlanta (Table 4).

Model results have also been used to estimate local or national urban tree effects on air pollution removal (Nowak et al. 2006a), 
Table 4. Estimates of total number of trees and standard error (SE), tree density, percent tree cover, leaf area index (LAI), and most common tree species from 14 cities analyzed using the UFORE model. ${ }^{2}$

\begin{tabular}{|c|c|c|c|c|c|c|c|c|c|}
\hline \multirow[b]{2}{*}{ City } & \multicolumn{2}{|c|}{ Number of trees } & \multirow{2}{*}{$\begin{array}{l}\text { Tree density } \\
\text { (no./ha) }\end{array}$} & \multirow{2}{*}{$\begin{array}{l}\text { Tree cover } \\
(\%)\end{array}$} & \multirow[b]{2}{*}{$\mathrm{LAI}^{\mathrm{y}}$} & \multirow{2}{*}{$\begin{array}{l}\text { Most common } \\
\text { tree species }\end{array}$} & \multirow[b]{2}{*}{ Year } & \multirow{2}{*}{$\begin{array}{l}\text { Sample } \\
\text { type }^{\mathrm{x}}\end{array}$} & \multirow[b]{2}{*}{ No. of plots } \\
\hline & Total & $\mathrm{SE}$ & & & & & & & \\
\hline Atlanta, $\mathrm{GA}^{\mathrm{w}}$ & $9,415,000$ & 749,000 & 275.8 & 36.7 & 2.2 & Liquidambar styraciflua & 1997 & SR & 205 \\
\hline Baltimore, $\mathrm{MD}^{\mathrm{v}}$ & $2,571,000$ & 494,000 & 122.9 & 21.0 & 1.3 & Fagus grandifolia & 2004 & SR & 200 \\
\hline Boston, $\mathrm{MA}^{\mathrm{w}}$ & $1,183,000$ & 109,000 & 82.9 & 22.3 & 1.0 & Acer platanoides & 1996 & SR & 217 \\
\hline Casper, WY ${ }^{\mathrm{u}}$ & 123,000 & 16,000 & 22.5 & 8.9 & 0.3 & Populus sargentii & 2006 & RG & 234 \\
\hline Freehold, $\mathrm{NJ}^{\mathrm{t}}$ & 48,000 & 6,000 & 94.6 & 34.4 & 1.6 & Acer platanoides & 1998 & SR & 144 \\
\hline Jersey City, $\mathrm{NJ}^{\mathrm{t}}$ & 136,000 & 22,000 & 35.5 & 11.5 & 0.4 & Ailanthus altissima & 1998 & SR & 220 \\
\hline Minneapolis, $\mathrm{MN}^{\mathrm{s}}$ & 979,000 & 165,000 & 64.7 & 26.4 & 1.0 & Fraxinus pennsylvanica & 2004 & RG & 110 \\
\hline Moorestown, $\mathrm{NJ}^{\mathrm{t}}$ & 583,000 & 53,000 & 153.4 & 28.0 & 1.7 & Acer rubrum & 2000 & SR & 206 \\
\hline New York, $\mathrm{NY}^{\mathrm{w}}$ & $5,212,000$ & 719,000 & 65.2 & 20.9 & 0.9 & Ailanthus altissima & 1996 & SR & 206 \\
\hline Philadelphia, $\mathrm{PA}^{\mathrm{w}}$ & $2,113,000$ & 211,000 & 61.9 & 15.7 & 0.8 & Prunus serotina & 1996 & SR & 210 \\
\hline San Francisco, $\mathrm{CA}^{\mathrm{u}}$ & 668,000 & 98,000 & 55.7 & 11.9 & 0.4 & Eucalyptus globulus & 2004 & RG & 194 \\
\hline Syracuse, NYv & 876,000 & 119,000 & 134.7 & 23.1 & 1.2 & Acer saccharum & 2001 & SR & 197 \\
\hline Washington, $\mathrm{DC}^{\mathrm{r}}$ & $1,928,000$ & 224,000 & 121.1 & 28.6 & 1.0 & Fagus grandifolia & 2004 & RG & 201 \\
\hline Woodbridge, $\mathrm{NJ}^{\mathrm{t}}$ & 986,000 & 97,000 & 164.3 & 29.5 & 1.6 & Liquidambar styraciflua & 2000 & SR & 215 \\
\hline
\end{tabular}

${ }^{\mathrm{z}}$ Divide tree density (no./ha) by 2.471 to convert to no./ac.

${ }^{\mathrm{y}}$ Total tree leaf area divided by total city area.

${ }^{\mathrm{x}} \mathrm{SR}=$ stratified random; $\mathrm{RG}=$ randomized grid.

wData collected by ACRT, Inc.

'Data collected by U.S. Forest Service.

"Data collected by city personnel.

tData collected by New Jersey Department of Environmental Protection.

s Data collected by Davey Resource Group.

'Data collected by Casey Trees Endowment Fund and National Park Service.

carbon storage and sequestration (Nowak and Crane 2002), oxygen production (Nowak et al. 2007a), structural value (Nowak et al. 2002a), VOC emissions (Nowak et al. 2002b) and building energy conservation, urban forest structure, and potential pest impacts (Nowak et al. 2002b, 2006b, 2006c, 2006d, 2007b, 2007c, 2007d).

\section{DISCUSSION}

The main advantages of the UFORE model are that it uses locally measured field data and the best available peer-reviewed procedures to estimate urban forest functions. Also, it is a publicly available model with technical support and training through i-Tree. However, UFORE also has limitations. Functional quantifications are estimates based on various algorithms. Many of the functions estimated by the model are difficult to accurately measure in the field; thus, modeling procedures are needed to quantify these effects for urban forests. Because model estimates are only as good as the field data inputs, quality assurance of field data accuracy is important.

The model only estimates structure and functions at one point in time but provides a means through permanent recording of plot and tree locations to accurately assess urban forest change through time. The model focuses on estimating structure and ecosystem services. The Urban Forest Effect model uses economic values from the literature to ascribe a value to these services. These economic values are straight multipliers (e.g., \$/ton) so users can easily substitute their own values if desired. Specific advantage and disadvantages of each module are discussed subsequently.

\section{Urban Forest Structure}

This is one of the most accurate modules in the UFORE program because the majority of the estimates are derived directly from the field measurements. If the field variables (e.g., species, dbh, ht) are measured accurately, then the UFORE model can give accurate estimates of structural variables (e.g., number of trees, species, and dbh distribution) with known standard error (uncertainty of estimate). The optimal urban forest sample and plot size continue to be investigated, but basic information on this topic is provided in Nowak et al. (2008). Cross-comparisons among cities can be conducted relatively easily with a standardized protocol and approximately 2000.04 ha $(0.1 \mathrm{ac})$ plots per city. In addition, the model can be easily used in many areas using plot sampling and data collection tools along with model distribution and support through i-Tree (www.itreetools.org). The Urban Forest Effect model offers a means to accurately detect changes in urban forest structure and functions through the use of permanent plots. However, the field data must be collected during the in-leaf season to measure various required crown parameters needed to estimate leaf area, leaf biomass, and tree health. The structural information provided is designed to aid in management and to estimate ecosystem functions. Numerous standard tables are produced that display the basic structural data by species, dbh class, condition class, and/or land use class.

Some of the key variables to assess ecosystem functions are leaf area and leaf biomass. These attributes are not directly measured in the field, but rather they are estimated using regression equations. These equations estimate the leaf area or biomass based on species type, crown measures, and tree condition. Other methods can be used to estimate leaf area (e.g., light imaging devices). In tests of various methods against measured tree leaf data, the regression equations used in UFORE were among the best for estimating leaf area of open-grown trees and ease of application (Peper and McPherson 1998). Also, there was no significant difference between the regression equation estimates and the measured tree leaf data (Peper and McPherson 1998).

There are also limitations related to the structural value estimates. These limitations include limited state costs and species 
factors from local ISA chapters and somewhat outdated values (from late 1990s to early 2000s). In addition, the condition and location factors used are not directly from the methods in the last CTLA guidelines, but rather the model uses dieback as a proxy for condition and land use as a proxy for location. Thus, the actual individual tree estimates can be unreliable, because the model uses average land use values; but across the population, the model should produce accurate estimates of total structural value.

With regard to pest potentials, only a few pests currently exist in the model, but the model has the capability to add other pests as host-preference data are obtained. The model only estimates potential maximum pest damage. Actual damage is likely to be much less than the potential for some pests or maximum damage may not be reached for several years or at all depending on local management activities and random factors.

\section{Biogenic Emissions}

Biogenic VOC emissions follow the protocols developed within the Biogenic Emissions Inventory System of the National Oceanic and Atmospheric Administration/U.S. Environmental Protection Agency (2008). The model produces results that are within range of biogenic VOC emission studies (e.g., Kinnee et al. 1997) and has the advantage of using local urban tree leaf biomass and weather data. The biogenic VOC model was developed in the early 2000s and may need to be updated based on the latest biogenic VOC modeling procedures (e.g., National Center for Atmospheric Research 2008).

\section{Carbon Storage and Sequestration}

The main advantage of the carbon estimation in UFORE is that it is based on a statistical sample of trees within an urban area and statistically estimates diameter distribution by species. The modeled carbon values are estimates based on forest-derived allometric equations. The carbon estimates yield a standard error of the estimate based on sampling error rather than error of estimation. Estimation error is unknown and likely larger than the reported sampling error. Estimation error includes the uncertainty of using biomass equations and conversion factors, which may be large, as well as measurement error, which is typically very small. The standardized carbon values (e.g., $\mathrm{kg} \mathrm{C/ha}$ or lbs $\mathrm{C} / \mathrm{ac}$ of tree cover) produced by UFORE fall within the range of other field studies of forest carbon (Nowak and Crane 2002).

However, there are various means to help improve the carbon storage and sequestration estimates for urban trees. Carbon estimates for open-grown urban trees are adjusted downward based on field measurements of trees in the Chicago area (Nowak 1994c). This adjustment may lead to conservative estimates of carbon. More research is needed on the applicability of forestderived equations to urban trees. In addition, more urban tree growth data are needed to better understand regional variability of urban tree growth under differing site conditions (e.g., tree competition) for better annual sequestration estimates. Average regional growth estimates are used based on limited measured urban tree growth data standardized to length of growing season and crown competition. Street tree growth data collected as part of i-Tree's STRATUM model will provide for better growth modeling in the near future.

There are currently limited biomass equations for palm trees or tropical trees in UFORE. The model needs to be updated with tropical tree biomass equations for more accurate estimates in tropical cities. Also, future research is needed to obtain biomass equations for urban or ornamental tree species. Tree decay is not accounted for in the carbon estimates, which may lead to an overestimate of carbon storage. A better understanding of the magnitude of decay in urban trees is needed.

\section{Air Pollution Removal}

The pollution removal module is designed to use standardized local weather and air pollution data in conjunction with field data measures to estimate pollution removal. The weather data are available across the globe in a standardized format from the National Climatic Data Center (2008). The pollution data are also readily available for the United States in a standardized format from the U.S. Environmental Protection Agency (2008). For analyses outside of the United States, local hourly pollution data need to be attained from local agencies and formatted to fit the UFORE input data structure. For analyses within the United States, users only need to supply local field data to operate the model.

The model uses a gas-exchange dry deposition model initially developed by the Oak Ridge National Laboratory (Baldocchi et al. 1987; Baldocchi 1988) to estimate hourly removal of $\mathrm{NO}_{2}$, $\mathrm{SO}_{2}$, and $\mathrm{O}_{3}$. For $\mathrm{CO}$ or PM10 removal, the model uses average deposition velocities from the literature in conjunction with local hourly pollution concentration and field data. The UFORE model's hourly pollution removal estimates are within bounds of field measurements of dry deposition velocities and follow daily gas exchange patterns (e.g., Lovett 1994). Methods to estimate the effects on PM2.5 are currently being developed for UFORE, but pollution removal of PM2.5 by trees is small in terms of magnitude of removal ( $\mathrm{T}$. Whitlow Cornell University, pers. comm., 2008)

\section{Building Energy Effects}

The base energy effect tables used are based on computer models of building energy use across the United States for various tree configurations (McPherson and Simpson 1999). The model produces estimates of tree effects at the local municipal scale based on state averages. Improved estimates of energy use could be made by modeling actual building types found in the field samples, but the cost and practicality of this type of local analysis limits this approach in energy modeling. Updated energy tables of types of energy use in buildings (e.g., electricity versus gas or oil) and possibly more locally based tables (e.g., county scale) would aid in improving estimates of energy effects by trees. Unfortunately, this type of local data is not currently available in a national database.

Cost estimates are based on average 2002 state average costs but are currently being updated to 2007 values (latest costs available nationally). Because the model is geared toward U.S. climate and building types, this module is not appropriate for use outside of the United States, except for possibly in southern Canada.

The model is currently being rewritten in $\mathrm{C}++$ to allow for seamless integration within i-Tree. Currently, users collect and enter data, which are sent to the Forest Service for processing and results typically returned to the user within 3 to 4 weeks. Once the user receives the results file, they can produce numerous standard tables and graphs, print an automated report, and/or 
export results to produce their own customized report. In addition to the new $\mathrm{C}++$ software, the UFORE model continues to be developed with new updates planned over the next several years, including integration with spatial tree cover maps.

The Urban Forest Effect model can be used to provide necessary information on the urban forest resource and its ecosystem services to improve urban forest management and bolster urban forestry programs. As an example, based in part on UFORE results, Conectiv Electric Utility negotiated to have \$1 million of an air pollution fine donated to the New Jersey Tree Foundation (a nonprofit organization working with the Community Forestry Program) for a massive Urban Airshed Reforestation project in the Camden, New Jersey, area (New Jersey Department of Environmental Protection 2002; M. D'Errico, New Jersey Parks and Community Forestry, pers. comm., 2002). In Oakville, Ontario, the town is using UFORE results to help better integrate forestry with other town departments and create new programs and policies to sustain tree cover and environmental quality for future generations (McNeil and Vava 2006).

The UFORE model was developed to statistically assess urban forest structure and subsequently estimate various functions and values based on these structural data and local environmental data. The structural data are critical to estimating functions, but are also essential to improve urban forest planning. Because the forest structure determines the functions derived from the urban forest, decisions that affect urban forest structure influence the current and future forest functions. Large-scale management decisions related to tree removal, species selection, tree location, tree health, and tree planting should incorporate local urban forest data and consider desired future forest functions.

\section{CONCLUSION}

The various sampling approaches provided through the UFORE model offer a relatively straightforward means to effectively assess urban forest structure and subsequently urban forest ecosystem functions and values. Although the model has various limitations, results are based on local field data and currently provide one of the most accurate means to assess urban forest structure and ecosystem functions. Structural data can be monitored to assess urban forest change and help develop and assess long-term management plans to meet the needs of an urban society and improve environmental quality and human health.

Acknowledgments. Data collection in Baltimore, funded by the USDA Forest Service, is part of the National Science Foundation's Long-Term Ecosystem Research project. Data from cities in New Jersey were collected and analyzed in cooperation with Mike D'Errico and the State of New Jersey, Department of Environmental Protection and Energy, Division of Parks and Forestry; Casper data collection was in cooperation with Mark Hughes of the Wyoming State Forestry Division and Jim Gerhart of the City of Casper Parks Division; Minneapolis data collection was by Davey Resource Group; San Francisco data collection was by Alexis Harte and the City of San Francisco; Washington DC data collection was by Casey Trees Endowment Fund and the National Park Service; and Atlanta, GA; Boston, MA; New York, NY; and Philadelphia, PA data were collected by ACRT, Inc.

\section{LITERATURE CITED}

Baldocchi, D. 1988. A multi-layer model for estimating sulfur dioxide deposition to a deciduous oak forest canopy. Atmospheric Environment 22:869-884.

Baldocchi, D.D., B.B. Hicks, and P. Camara. 1987. A canopy stomatal resistance model for gaseous deposition to vegetated surfaces. Atmospheric Environment 21:91-101.

Barbour, M.G., J.H. Burk, and W.D. Pitts. 1980. Terrestrial Plant Ecology. Benjamin/Cummings, Menlo Park, CA. 604 pp.

Bidwell, R.G.S., and D.E. Fraser. 1972. Carbon monoxide uptake and metabolism by leaves. Canadian Journal of Botany 50:1435-1439.

Boyd, J.B. 1983. Natural Reproduction of Exotic and Indigenous Trees in Three Urban Environments. M.S. Thesis, Univ. of Wisconsin, Milwaukee, WI. 97 pp.

Brasseur, G.P., and R.B. Chatfield. 1991. The fate of biogenic trace gases in the atmosphere, pp. 1-27. In: Sharkey, T.D., E.A. Holland, and H.A. Mooney (Eds.). Trace Gas Emissions by Plants. Academic Press, New York, NY.

Burns, R.M., and B.H. Honkala. 1990a. Silvics of North America. Vol. 1. Conifers. Agric. Handb. 654. U.S. Department of Agriculture, Washington, DC. 675 pp.

. 1990b. Silvics of North America. Vol. 2. Hardwoods. Agric. Handb. 654. U.S. Department of Agriculture, Washington, DC. 877 $\mathrm{pp}$

Buckelew Cumming, A., D.J. Nowak, D.B. Twardus, R. Hoehn, M. Mielke, and R. Rideout. 2007. Urban Forests of Wisconsin 2002: Pilot Monitoring Project 2002. USDA Forest Service, Northeastern Area State and Private Forestry Report, NA-FR-05-07. 33 pp. www.treesearch.fs.fed.us/pubs/12685 (accessed 10/1/08).

Cairns, M.A., S. Brown, E.H. Helmer, and G.A. Baumgardner. 1997. Root biomass allocation in the world's upland forests. Oecologia 111:1-11.

The Capital District Regional Planning Commission. 2008. Consumer and Producer Price Indices. www.cdrpc.org/CPI_PPI.html (accessed 6/5/08).

Chow, P., and G.L. Rolfe. 1989. Carbon and hydrogen contents of short-rotation biomass of five hardwood species. Wood and Fiber Science 21:30-36.

Clark, D.E. 1979. Sunset New Western Garden Book. Lane Publ. Co., Menlo Park, CA. 512 pp.

Council of Tree and Landscape Appraisers. 1992. Guide for Plant Appraisal. International Society of Arboriculture, Savoy, IL. 103 pp.

Derrenbacher, W.E. 1969. Plants and Landscape: An Analysis of Ornamental Planting in Four Berkeley Neighborhoods. Master's Thesis, University of California, Berkeley, CA. $231 \mathrm{pp}$.

deVries, R.E. 1987. A Preliminary Investigation of the Growth and Longevity of Trees in Central Park. M.S. Thesis, Rutgers University, New Brunswick, NJ. 95 pp.

Dorney, J.R., G.R. Guntenspergen, J.R. Keough, and F. Stearns. 1984. Composition and structure of an urban woody plant community. Urban Ecology 8:69-90.

Duncan, J.S. Jr. 1973. Landscape taste as a symbol of group identity. Geographical Review 63:334-355.

Dwyer, J.F., E.G. McPherson, H.W. Schroeder, and R.A. Rowntree. 1992. Assessing the benefits and costs of the urban forest. Journal of Arboriculture 18:227-234.

Energy Information Administration. 2003a. Sales Revenue Data. 27 Jan 2003. www.eia.doe.gov/electricity/page/sales_revenue.xls (accessed $4 / 3 / 03)$.

- 2003b. Energy Markets and End Use. www.eia.doe.gov/emeu/ states/_states.html (accessed 4/3/03).

. 2003c. Natural Gas Monthly. 16 Apr 2003. www.eia.doe.gov/ pub/oil_gas/natural_gas/data_publications/natural_gas_monthly/ current/pdf/table_15.pdf (accessed 4/3/03).

— 2003d. Petroleum Marketing Monthly. Feb 2003. www.eia. doe.gov/pub/oil_gas/petroleum/data_publications/petroleum_ marketing_monthly/current/pdf/pmmtab18.pdf (accessed 4/3/03).

—. 2003e. Residential Energy Consumption Survey. 27 Feb 2001. www.eia.doe.gov/emeu/consumptionbriefs/recs/heating_oil/ region_oil.html (accessed 4/3/03).

. 2003f. Residential Energy Consumption Survey. 27 Feb 2001. http://eia.doe.gov/emeu/recs/glossary.html (accessed 4/3/03). 
Escobedo, F.J., D.J. Nowak, J.E. Wagner, C. Luz de la Maza, and M. Rodriguez. 2006. The socioeconomics and management of Santiago de Chile's public urban forest. Urban Forestry and Urban Greening 4:105-114.

Fankhauser, S. 1994. The social costs of greenhouse gas emissions: An expected value approach. The Energy Journal 15:157-184.

Fleming, L.E. 1988. Growth Estimation of Street Trees in Central New Jersey. M.S. Thesis, Rutgers University, New Brunswick, NJ. 143 pp.

Forest Products Laboratory. 1952. Chemical Analyses of Wood. Tech. Note 235. U.S. Department of Agriculture, Forest Service, Forest Products Laboratory, Madison, WI. 4 pp.

Frelich, L.E. 1992. Predicting Dimensional Relationships for Twin Cities Shade Trees. University of Minnesota, Department of Forest Resources, St. Paul, MN. 33 pp.

Geron, C.D., A.B. Guenther, and T.E. Pierce. 1994. An improved model for estimating emissions of volatile organic compounds from forests in the eastern United States. Journal of Geophysical Research 99: 12773-12791.

Gilbert, O.L. 1989. The Ecology of Urban Habitats. Chapman and Hall, London, UK. 369 pp.

Gleason, H.A., and A. Cronquist. 1991. Manual of vascular plants of Northeastern United States and Adjacent Canada. New York Botanical Garden, Bronx, NY. 910 pp.

Grimm, W.C. 1962. The Book of Trees. Stackpole Co., Harrisburg, PA. 487 pp.

Ham, D., C. Post, D. Vanblaricom, D. Lipscomb, D. Hargett, and D.J. Nowak. 2003. Analysis of the explosively urbanizing South Carolina Interstate 85 corridor. Proceedings of the 2003 National Urban Forest Conference, San Antonio, TX, September 17-20, 2003.

Hough, R.B. 1907. Handbook of the Trees of the Northern States and Canada. R. B. Hough, Lowville, NY. 470 pp.

Hyams, E.S. 1970. English Cottage Gardens. Nelson, London, UK. 234 pp.

Iizumi, S. 1983. The urban vegetation of Tokyo and Sendai, Japan, pp. 335-340. In: Holzner, W., M.J. Werger, and I. Ikusima (Eds.). Man's Impact on Vegetation. Dr. W. Junk Publishers, The Hague, The Netherlands.

International Society of Arboriculture. 1988. Valuation of Landscape Trees, Shrubs, and Other Plants. International Society of Arboriculture, Champaign, IL. 50 pp.

i-Tree. 2008. i-Tree Software Suite v2.0. 239 pp. www.itreetools.org/ resource_learning_center/elements/i-Tree_v20_UsersManual.pdf (accessed 10/1/08).

Jarvis, P.G., and J.W. Leverenz. 1983. Productivity of temperate, deciduous and evergreen forests, pp. 233-280. In: Lange, O.L., P.S. Nobel, C.B. Osmond, and H. Ziegler (Eds.). Physiological Plant Ecology IV, Encyclopedia of Plant Physiology. Vol. 12D. SpringerVerlag, Berlin, Germany.

Jones, A.W. 1957. The flora of the city of London bombed sites. The London Naturalist 37:189-210.

Jim, C.Y. 1989. The distribution and configuration of tree cover in urban Hong Kong. GeoJournal 18:175-188.

Kinnee, E., C. Geron, and T. Pierce. 1997. United States land use inventory for estimating biogenic ozone precursor emissions. Ecological Applications 7:46-58.

Kunick, W. 1982. Comparison of the flora of some cities of the central European lowlands, pp. 13-22. In: Bornkamm, R., J.A. Lee, and M.R. Seaward (Eds.). Urban Ecology. Blackwell Science Publication, Oxford, UK

Kuo, F.E., and W.C. Sullivan. 2001. Environment and crime in the inner city: Does vegetation reduce crime? Environment and Behavior 33: 343-365

Leverenz, J.W., and T.M. Hinckley. 1990. Shoot structure, leaf area index and productivity of evergreen conifer stands. Tree Physiology 6:135-149.

Liebhold, A.M., K.W. Gottschalk, R. Muzika, M.E. Montgomery, R. Young, K. O’Day, and B. Kelley. 1995. Suitability of North Ameri- can Tree Species to the Gypsy Moth: A Summary of Field and Laboratory Tests. Gen. Tech. Rep. NE-211. U.S. Department of Agriculture, Forest Service, Northeastern Forest Experiment Station, Radnor, PA. 34 pp.

Little, E.L. 1971. Atlas of United States Trees. Vol. 1. Conifers and Important Hardwoods. Misc. Pub. 1146. U.S. Department of Agriculture, Forest Service, Washington, DC. 400 pp.

. 1976. Atlas of United States Trees. Vol. 3. Minor Western Hardwoods. Misc. Pub. 1314. U.S. Department of Agriculture, Forest Service, Washington, DC. 300 pp.

1977. Atlas of United States Trees. Vol. 4. Minor Eastern Hardwoods. Misc. Pub. 1342. U.S. Department of Agriculture, Forest Service, Washington, DC. 235 pp.

1978. Atlas of United States Trees. Vol. 5. Florida. Misc. Pub. 1361. U.S. Department of Agriculture, Forest Service, Washington, DC. $138 \mathrm{pp}$

Lovett, G.M. 1994. Atmospheric deposition of nutrients and pollutants in North America: An ecological perspective. Ecological Applications 4:629-650.

Lozano, J.V. 2004. Distribucion del arbolado urbano en la ciudad de Fuenlabrada y su contribucion a la calidad del aire. Ciudad y Territorio. Estudios Territoriales 36:419-427.

Maxwell, E.L. 1994. A meteorological/statistical solar radiation model, pp. 421-426. In: Proceedings of the 1994 Annual Conference of the American Solar Energy Society. American Solar Energy Society, San Jose, CA.

McBride, J.R., and D.F. Jacobs. 1976. Urban forest development: A case study, Menlo Park, California. Urban Ecology 2:1-14.

. 1986. Presettlement forest structure as a factor in urban forest development. Urban Ecology 9:245-266.

McNeil, J., and C. Vava. 2006. Oakville's Urban Forest: Our Solution to Our Pollution. Town of Oakville Report, Oakville, Ontario. 67 pp. www.oakville.ca/Media_Files/forestry/UFORE.pdf (accessed 10/1/ 08).

McPherson, E.G. 1998. Structure and sustainability of Sacramento's urban forest. Journal of Arboriculture 24:174-190.

McPherson, E.G., and J.R. Simpson. 1999. Carbon Dioxide Reduction Through Urban Forestry: Guidelines for Professional and Volunteer Tree Planters. Gen. Tech. Rep. PSW-171. U.S. Department of Agriculture, Forest Service, Pacific Southwest Research Station, Albany, CA. 237 pp.

Miller, P.R., and A.M. Winer. 1984. Composition and dominance in Los Angeles Basin urban vegetation. Urban Ecology 8:29-54.

Monteith, J.L., and M.H. Unsworth. 1990. Principles of Environmental Physics. Edward Arnold, New York, NY. 291 pp.

Moran, M.A. 1984. Influence of adjacent land use on understory vegetation of New York forests. Urban Ecology 8:329-340.

Murray, F.J., L. Marsh, and P.A. Bradford. 1994. New York State Energy Plan, Vol. II: Issue Reports. New York State Energy Office, Albany, NY.

National Center for Atmospheric Research. 2008. Model of Emissions of Gases and Aerosols from Nature (MEGAN). http://bai.acd ucar.edu/Megan/ (accessed 10/1/08).

National Climatic Data Center. 2008. Integrated Surface Hourly Observations. http://ols.nndc.noaa.gov/plolstore/plsq1/olstore. prodspecific?prodnum $=$ C00353-CDR-S0001 $($ accessed 6/5/08).

National Oceanic and Atmospheric Administration/U.S. Environmental Protection Agency. 2008. Biogenic Emissions Inventory System (BEIS) Modeling. /www.epa.gov/asmdnerl/biogen.html (accessed 10/1/08).

New Jersey Department of Environmental Protection. 2002. DEP Announces \$1 Million Urban Airshed Reforestation Project From Conectiv Enforcement Settlement. Press release 02/111, 10/26/02. www. state.nj.us/dep/newsrel/releases/02_0111.htm (accessed 10/1/08).

Nowak, D.J. 1991. Urban Forest Development and Structure: Analysis of Oakland, California. Ph.D. Dissertation, University of California, Berkeley, CA. 232 pp. 
1994a. Understanding the structure of urban forests. Journal of Forestry 92:42-46.

- 1994b. Urban forest structure: The state of Chicago's urban forest, pp. 3-18, 140-164. In: McPherson, E.G, D.J. Nowak, and R.A. Rowntree (Eds.). Chicago's Urban Forest Ecosystem: Results of the Chicago Urban Forest Climate Project. USDA Forest Service General Technical Report NE-186.

- 1994c. Atmospheric carbon dioxide reduction by Chicago's urban forest, pp. 83-94. In: McPherson, E.G., D.J. Nowak, and R.A. Rowntree (Eds.). Chicago's Urban Forest Ecosystem: Results of the Chicago Urban Forest Climate Project. Gen. Tech. Rep. NE-186. U.S. Department of Agriculture, Forest Service, Northeastern Forest Experiment Station, Radnor, PA.

. 1996. Estimating leaf area and leaf biomass of open-grown deciduous urban trees. Forest Science 42:504-507.

Nowak, D.J., K.L. Civerolo, S.T. Rao, G. Sistla, C.J. Luley, and D.E. Crane. 2000. A modeling study of the impact of urban trees on ozone. Atmospheric Environment 34:1601-1613.

Nowak, D.J., and D.E. Crane. 2000. The urban forest effects (UFORE) model: Quantifying urban forest structure and functions, pp. 714-720. In: Hansen M., and T. Burk (Eds.). In: Proceedings Integrated Tools for Natural Resources Inventories in the 21st Century. IUFRO Conference, 16-20 August 1998, Boise, ID. General Technical Report NC-212, U.S. Department of Agriculture, Forest Service, North Central Research Station, St. Paul, MN.

. 2002. Carbon storage and sequestration by urban trees in the USA. Environmental Pollution 116:381-389.

Nowak, D.J., D.E. Crane, and J.F. Dwyer. 2002a. Compensatory value of urban trees in the United States. Journal of Arboriculture 28: 194-199.

Nowak, D.J., D.E. Crane, and J.C. Stevens. 2006a. Air pollution removal by urban trees and shrubs in the United States. Urban Forestry and Urban Greening 4:115-123.

Nowak, D.J., D.E. Crane, J.C. Stevens, and M. Ibarra. 2002b. Brooklyn's Urban Forest. General Technical Report NE-290, U.S. Department of Agriculture, Forest Service, Northeastern Research Station, Newtown Square, PA. 107 pp.

Nowak, D.J., and J.F. Dwyer. 2007. Understanding the benefits and costs of urban forest ecosystems, pp. 25-46. In: Kuser, J. (Ed.). Urban and Community Forestry in the Northeast. Springer Science and Business Media, New York, NY.

Nowak, D.J., R.H. Hoehn, and D.E. Crane. 2007a. Oxygen production by urban trees in the United States. Arboriculture and Urban Forestry 33:220-226.

Nowak, D.J., R. Hoehn, D.E. Crane, J.C. Stevens, and J.T. Walton. 2006b. Assessing Urban Forest Effects and Values: Minneapolis' Urban Forest. Resource Bulletin NE-166. U.S. Department of Agriculture, Forest Service, Northeastern Research Station, Newtown Square, PA. 20 pp.

2006c. Assessing Urban Forest Effects and Values: Washington, DC's Urban Forest. Resource Bulletin NRS-1. U.S. Department of Agriculture, Forest Service, Northern Research Station, Newtown Square, PA. 24 pp.

. 2006d. Assessing Urban Forest Effects and Values: Casper's Urban Forest. Resource Bulletin NRS-4. U.S. Department of Agriculture, Forest Service, Northern Research Station, Newtown Square, PA. 20 pp.

. 2007b. Assessing Urban Forest Effects and Values: Philadelphia's Urban Forest. Resource Bulletin NRS-7. U.S. Department of Agriculture, Forest Service, Northern Research Station, Newtown Square, PA. 22 pp.

- . 2007c. Assessing Urban Forest Effects and Values: San Francisco's Urban Forest. Resource Bulletin NRS-8. U.S. Department of Agriculture, Forest Service, Northern Research Station, Newtown Square, PA. 22 pp.

2007d. Assessing Urban Forest Effects and Values: New York
City's Urban Forest. Resource Bulletin NRS-9. U.S. Department of Agriculture, Forest Service, Northern Research Station, Newtown Square, PA. 22 pp.

Nowak, D.J., P.J. McHale, M. Ibarra, D. Crane, J. Stevens, and C. Luley. 1998. Modeling the effects of urban vegetation on air pollution, pp. 399-407. In: Gryning, S.E., and N. Chaumerliac (Eds.). Air Pollution Modeling and Its Application XII. Plenum Press, New York, NY.

Nowak, D.J., and P. O'Connor. 2001. Syracuse Urban Forest Master Plan: Guiding the City's Forest Resource in the 21st Century. USDA Forest Service General Technical Report. 50 pp.

Nowak, D.J., J. Pasek, R. Sequeira, D.E. Crane, and V. Mastro. 2001. Potential effect of Anoplophora glabripennis (Coleoptera: Cerambycidae) on urban trees in the United States. Journal of Economic Entomology 94:116-122.

Nowak, D.J., R.A. Rowntree, E.G. McPherson, S.M. Sisinni, E. Kerkmann, and J.C. Stevens. 1996. Measuring and analyzing urban tree cover. Landscape and Urban Planning 36:49-57.

Nowak, D.J., J.T. Walton, J.C. Stevens, D.E. Crane, and R.E. Hoehn. 2008. Effect of plot and sample size on timing and precision of urban forest assessments. Arboriculture and Urban Forestry 34:386-390.

Numata, M. 1977. The impact of urbanization on vegetation in Japan, pp. 161-171. In: Miyawaki, A., and Tuxen, R. (Eds.). Vegetation Science and Environmental Protection. Maruzen Co. Ltd., Tokyo, Japan.

Onstad, D.W., D.J. Nowak, and M.R. Jeffords. 1997. Potential defoliation of trees by outbreak populations of gypsy moth in the Chicago area. Journal of Arboriculture 23:57-64.

Peper, P.J., and E.G. McPherson. 1998. Comparison of five methods for estimating leaf area index of open-grown deciduous trees. Journal of Arboriculture 24:98-111.

Platt, R. 1968. Discover American Trees. Dodd, Mead and Co., New York, NY. 256 pp.

Preston, R.J. 1976. North American Trees. Iowa State University Press, Ames, IA. 399 pp.

Profous, G. 1984. Forest changes in the Bronx. Journal of Forestry 82:559-560.

Profous, G., R.A. Rowntree, and R.E. Loeb. 1988. The urban forest landscape of Athens, Greece: Aspects of structure, planning and management. Arboricultural Journal 12:83-107.

Richards, N.A., J.R. Mallette, R.J. Simpson, and E.A. Macie. 1984. Residential greenspace and vegetation in a mature city: Syracuse, New York. Urban Ecology 8:99-125.

Rowntree, R.A. 1984. Forest canopy cover and land use in four eastern United States cities. Urban Ecology 8:55-67.

Sanders, R.A. 1983. Configuration of tree canopy cover in urban land uses. Geographical Perspectives 51:49-53.

Santamour, F.S. Jr. 1983. Woody-plant succession in the urban forest: Filling cracks and crevices. Journal of Arboriculture 9:267-270.

Schmid, J.A. 1975. Urban Vegetation: A Review and Chicago Case Study. Vol. 161. Research Paper, Dept. of Geography, Univ. of Chicago, Chicago, IL. 266 pp.

Smith, F.W., D.A. Sampson, and J.N. Long. 1991. Comparison of leaf area index estimates from allometrics and measured light interception. Forest Science 37:1682-1688.

Smith, W.B., and S.R. Shifley. 1984. Diameter Growth, Survival, and Volume Estimates for Trees in Indiana and Illinois. Res. Pap. NC257. U.S. Department of Agriculture, Forest Service, North Central Forest Experiment Station, St. Paul, MN. 10 pp.

Sukopp, H., H.P. Blume, and W. Kunick. 1979. The soil, flora, and vegetation of Berlin's waste lands, pp. 115-132. In: Laurie, I. (Ed.). Nature in Cities. John Wiley and Sons, New York, NY.

U.S. Department of Labor and Statistics. 2003. Consumer Price Indices. 16 Apr 2003. www.ftp.bls.gov/pub/special.requests/cpi/cpiai.txt (accessed 4/3/03).

U.S. Environmental Protection Agency. 2008. Technology Transfer Network (TTN) Air Quality System (AQS). www.epa.gov/ttn/airs/ airsaqs/detaildata/downloadaqsdata.htm (accessed 10/1/08). 
Viereck, L.A., and E.L. Little. 1975. Atlas of United States Trees. Vol. 2. Alaska Trees and Common Shrubs. Misc. Publ. 1293. U.S. Department of Agriculture, Forest Service, Washington, DC. 109 pp.

Westphal, L.M. 2003. Urban greening and social benefits: A study of empowerment outcomes. Journal of Arboriculture 29:137-147.

Whitney, G.G. 1985. A quantitative analysis of the flora and plant communities of a representative midwestern U.S. town. Urban Ecology 9:143-160.

Winer, A.M., D.R. Fitz, P.R. Miller, R. Atkinson, D.E. Brown, W.P. Carter, M.C. Dodd, C.W. Johnson, M.A. Myers, K.R. Neisess, M.P. Poe, and E.R. Stephens. 1983. Investigation of the Role of Natural Hydrocarbons in Photochemical Smog Formation in California. Statewide Air Pollution Research Center, Riverside, CA.

Wolf, K.M. 2003. Public response to the urban forest in inner-city business districts. Journal of Arboriculture 29:117-126.

Yang, J., J. McBride, J. Zhou, and Z. Sun. 2005. The urban forest in Beijing and its role in air pollution reduction. Urban Forestry and Urban Greening 3:65-78.

Zinke, P.J. 1967. Forest interception studies in the United States, pp. 137-161. In: Sopper, W.E., and H.W. Lull (Eds.). Forest Hydrology. Pergamon Press, Oxford, UK.

David J. Nowak (corresponding author)

USDA Forest Service

Northern Research Station

5 Moon Library

SUNY-ESF

1 Forestry Drive

Syracuse, NY 13210, U.S.

dnowak@fs.fed.us

Daniel E. Crane

USDA Forest Service

Northern Research Station

5 Moon Library

SUNY-ESF

1 Forestry Drive

Syracuse, NY 13210, U.S.

Jack C. Stevens

USDA Forest Service

Northern Research Station

5 Moon Library

SUNY-ESF

1 Forestry Drive

Syracuse, NY 13210, U.S.

Robert E. Hoehn

USDA Forest Service

Northern Research Station

5 Moon Library

SUNY-ESF

1 Forestry Drive

Syracuse, NY 13210, U.S.
Jeffrey T. Walton

Paul Smith's College

Routes 86 \& 30

P.O. Box 265

Paul Smiths, NY 12970-0265, U.S.

Jerry Bond

Consulting Urban Forester

Urban Forestry LLC

3904 Willowdale Lane

Geneva, NY 14456-9267, U.S.

Résumé. Pour gérer adéquatement la forêt urbaine, il est essentiel d'avoir des données sur cette importante ressource. Une manière efficace d'obtenir cette information est d'échantillonner aléatoirement les zones urbaines. Afin d'aider à évaluer la structure de la forêt urbaine (ex.: nombre d'arbres, composition en espèces, dimensions des arbres, santé) et plusieurs de ses fonctions (ex.: captage des polluants atmosphériques, captage du carbone et séquestration), le modèle des effets de la forêt urbaine (UFORE, Urban Forest Effects) a été développé. Les variables collectées ainsi que les méthodes de modélisation sont détaillées et les résultats de la structure de la forêt urbaine sont comparés parmi 14 villes des États-Unis avec une densité moyenne en arbres variant de 22,5 arbres/ha à Casper au Wyoming jusqu'à 275,8 arbres/ha à Atlanta en Géorgie. Les avantages et les désavantages de cette méthode terrestre d'évaluation de la structure de la forêt urbaine, de ses fonctions et de ses valeurs sont discutés.

Zusammenfassung. Um einen urbanen Forst richtig zu bewirtschaften, ist ein wichtig, auf Daten zurückgreifen zu können. Ein effizienter Ansatz hierfür ist eine stichprobenartige Erfassung von urbanen Flächen. Dafür wurde das UFORE (Modell zu Erfassung von urbanen Forsten und ihren Einflüssen) entwickelt. Es werden Datenerfassungsvariablen und Modell-Methoden beschrieben und die Ergebnisse der Umfrage in 14 US-Städten mit einer durchschnittlichen Baumdichte von 22,5 Bäumen/ha in Caspar, Wyoming bis hin zu 275,8 Bäumen/ha in Atlanta, Georgia verglichen. Die Vor- und Nachteile dieser Erfassungsmethode urbaner Forststrukturen, Funktionen und Werte werden hier diskutiert.

Resumen. Para manejar apropiadamente los bosques urbanos, es esencial tener datos de este importante recurso. Un medio eficiente de obtener esta información es muestrear aleatoriamente las áreas urbanas. Para ayudar a evaluar la estructura del bosque urbano (número de árboles, composición de especies, tamaño de los árboles, salud) y varias funciones (remoción de la polución del aire, almacenaje y secuestro de carbono), fue desarrollado el modelo Efectos del Bosque Urbano (UFORE, por sus siglas en inglés). Se detalla la colección de los datos de las variables y los métodos del modelo. Los resultados de la estructura del bosque urbano fueron comparados entre 14 ciudades de los Estados Unidos con densidades promedio de árboles entre 22.5 árboles/ ha (9.1 árboles/acre) en Casper, Wyoming, a 275 árboles/ha (111.6 árboles/acre) en Atlanta, Georgia. Se discuten las ventajas y desventajas de este método para evaluar la estructura, las funciones y los valores del bosque urbano. 